\title{
Sodium butyrate potentiates insulin secretion from rat islets at the expense of compromised expression of $\beta$ cell identity
}

\section{genes}

\author{
Shushu Wang ${ }^{1,2,3}$, Miaomiao Yuan ${ }^{1,2,3}$, Linlin Zhang ${ }^{1,2}$, Kecheng Zhu ${ }^{1,2}$, Chunxiang Sheng ${ }^{1,2}$, Feiye Zhou ${ }^{1,2}$, Zhaoqian Xu $^{1,2}$, \\ Qianqian Liu ${ }^{1,2}$, Yun Liu ${ }^{1,2}$, Jieli Lu (iD) ${ }^{1,2 \bowtie}$, Xiao Wang (iD ${ }^{1,2 \bowtie}$ and Libin Zhou (D ${ }^{1,2 \bowtie}$
}

(C) The Author(s) 2022

\begin{abstract}
Short-chain fatty acids (SCFAs) produced by the gut microbiota have been well demonstrated to improve metabolic homeostasis. However, the role of SCFAs in islet function remains controversial. In the present study, none of the sodium acetate, sodium propionate, and sodium butyrate (SB) displayed acute impacts on insulin secretion from rat islets, whereas long-term incubation of the three SCFAs significantly potentiated pancreatic $\beta$ cell function. RNA sequencing (RNA-seq) revealed an unusual transcriptome change in SB-treated rat islets, with the downregulation of insulin secretion pathway and $\beta$ cell identity genes, including Pdx1, MafA, NeuroD1, Gck, and Slc2a2. But these $\beta$ cell identity genes were not governed by the pan-HDAC inhibitor trichostatin A. Overlapping analysis of H3K27Ac ChIP-seq and RNA-seq showed that the inhibitory effect of SB on the expression of multiple $\beta$ cell identity genes was independent of H3K27Ac. SB treatment increased basal oxygen consumption rate (OCR), but attenuated glucose-stimulated OCR in rat islets, without altering the expressions of genes involved in glycolysis and tricarboxylic acid cycle. SB reduced the expression of Kcnj11 (encoding $\mathrm{K}_{\mathrm{ATP}}$ channel) and elevated basal intracellular calcium concentration. On the other hand, SB elicited insulin gene expression in rat islets through increasing H3K18bu occupation in its promoter, without stimulating CREB phosphorylation. These findings indicate that SB potentiates islet function as a lipid molecule at the expense of compromised expression of islet $\beta$ cell identity genes.
\end{abstract}

Cell Death and Disease (2022)13:67; https://doi.org/10.1038/s41419-022-04517-1

\section{INTRODUCTION}

The pancreatic $\beta$ cell plays a vital role in the maintenance of glucose homeostasis by secreting an appropriate amount of insulin [1]. Pancreatic $\beta$ cell dysfunction is one of the main contributors to the initiation and progression of type 2 diabetes [2]. To respond with an appropriate insulin release to fluctuating glucose levels, it is indispensable for $\beta$ cells to develop a maturation machinery that defines their functional identity. Intensive studies in animal models have led to the identification of multiple molecular markers which maintain the function and identity of $\beta$ cells, including Slc2a2, Gck, Pdx1, MafA, Nkx2-2, Nkx61 , and NeuroD1 [3-7]. The down-regulation of these important functional genes and transcription factors indicates the loss of mature $\beta$ cell identity. Protein acetylation is involved in the maintenance of $\beta$ cell function and identity. H3K27ac has been considered a key marker of cell identity [8]. The loss of $\beta$ cell identity under stressful environments such as glucotoxicity is usually accompanied by $\beta$ cell dedifferentiation towards progenitor-like cells or transdifferentiation to other islet cell types $[3,9]$.
As an energy sensor, the $\beta$ cell adapts its response to variations in the level of multiple circulating nutrients including glucose, amino acids, and free fatty acids (FFAs), showing great plasticity in insulin secretion [10]. Glucose-stimulated insulin secretion (GSIS) is completely ablated in lipid-depleted islets, whereas restoring FFAs rescues insulin secretion, indicating an important role of FFAs in modulating $\beta$ cell function [11, 12]. Fatty acids are grouped into long- (C12-C22), medium- (C7-C12), and short-chain fatty acids (SCFAs, C2-C6) according to their carbon chain length [13]. The insulinotropic effect of FFAs is profoundly influenced by chain length and degree of saturation [14].

SCFAs could be produced by the intestinal microbiota or by catabolism of long-chain fatty acids or branched-chain amino acids [15-17]. The three most common SCFAs, acetate, propionate, and butyrate have been demonstrated to increase insulin sensitivity, induce weight loss, reduce inflammation, etc [18]. However, no clear consensus has been achieved about the effect of SCFAs on $\beta$ cell function. Some studies reported that acetate, propionate, and butyrate potentiated GSIS [19-22], while others displayed a contrary result or no effects [23-25]. Besides as

\footnotetext{
'Department of Endocrine and Metabolic Diseases, Shanghai Institute of Endocrine and Metabolic Diseases, Ruijin Hospital, Shanghai Jiao Tong University School of Medicine, Shanghai, China. ${ }^{2}$ Shanghai National Clinical Research Center for Metabolic Diseases, Key Laboratory for Endocrine and Metabolic Diseases of the National Health Commission of the PR China, Shanghai National Center for Translational Medicine, Ruijin Hospital, Shanghai Jiao Tong University School of Medicine, Shanghai, China. ${ }^{3}$ These authors contributed equally: Shushu Wang, Miaomiao Yuan. ${ }^{凶}$ email: jielilu@hotmail.com; wangxiao1976@hotmail.com; libinzhou99@hotmail.com Edited by Professor Alessandro Finazzi-Agrã
}

Received: 27 July 2021 Revised: 14 December 2021 Accepted: 6 January 2022 Published online: 19 January 2022 


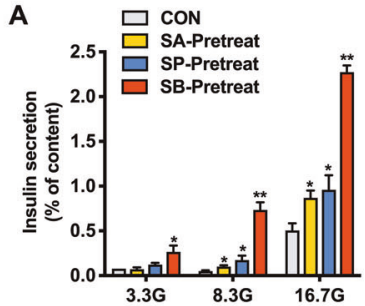

D

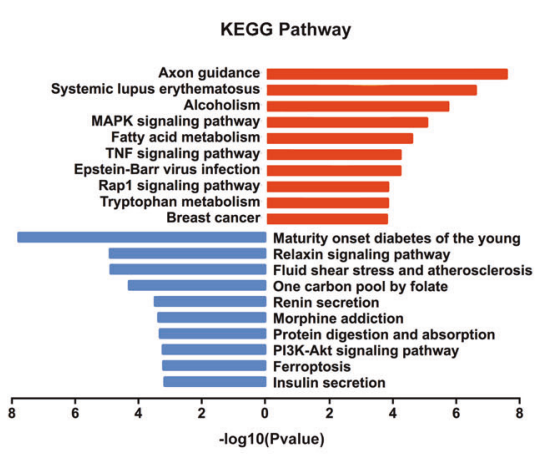

B

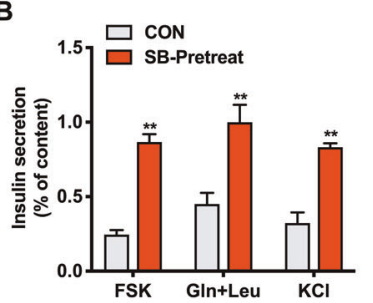

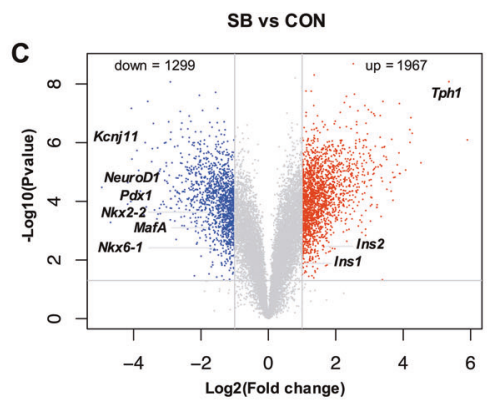

E

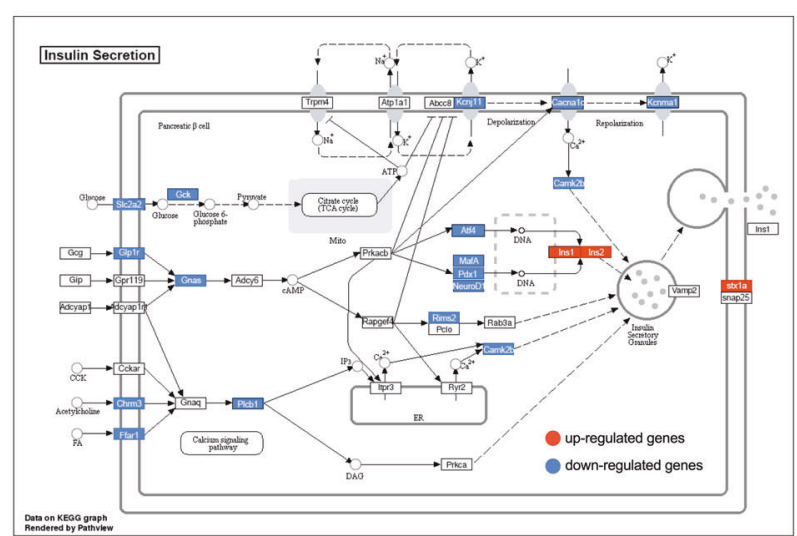

Fig. 1 Effects of short-chain fatty acids on insulin secretion and transcriptome in rat islets. A Rat islets were pretreated with $5 \mathrm{mM}$ sodium acetate (SA), $5 \mathrm{mM}$ sodium propionate (SP), and $5 \mathrm{mM}$ sodium butyrate (SB) at $3.3 \mathrm{mM}$ glucose for $24 \mathrm{~h}$, and then stimulated with $3.3,8.3$, or $16.7 \mathrm{mM}$ glucose for $1 \mathrm{~h}$. Insulin secretion was measured. B Rat islets were pretreated with $5 \mathrm{mM}$ SB at $3.3 \mathrm{mM}$ glucose for $24 \mathrm{~h}$, then stimulated with $10 \mu \mathrm{M}$ forskolin (FSK), $5 \mathrm{mM}$ glutamine (Gln) and leucine (Leu), and $35 \mathrm{mM} \mathrm{KCl}$ for $1 \mathrm{~h}$, and insulin secretion was measured. C Volcano plot of differentially expressed genes from RNA-seq analysis of isolated rat islets treated with or without $5 \mathrm{mM} \mathrm{SB}$ for $24 \mathrm{~h}$ ( $n=3$ ). The thresholds set for upregulated (red) and downregulated (blue) genes were a fold change $\geq 2.0$ and a $p$-value $\leq 0.05$. D KEGG pathway analysis of upregulated (red) and downregulated (blue) genes. E Differentially expressed genes in the insulin secretion KEGG pathway in SB-treated islets compared to the control islets. Green indicates downregulation (fold change $\leq 0.5$ ) and yellow indicates upregulation (fold change $\geq 2$ ). Gray label marks genes with non-significant changes. Data were given as mean \pm SD for three separate experiments. ${ }^{*} p<0.05$ and ${ }^{* *} p<0.01$ vs control (CON) group.

nutrient substrates, SCFAs act as signaling activators for the Gprotein-coupled-receptors as well as histone deacetylase (HDAC) inhibitors [26-28]. However, the mechanism underlying SCFAsregulated $\beta$ cell function remains uncertain.

In this current study, long-term incubation of three SCFAs sodium acetate (SA), sodium propionate (SP), or sodium butyrate (SB) significantly amplified insulin secretion from rat islets in response to glucose and amino acid. Unexpectedly, RNA sequencing (RNA-seq) revealed that SB downregulated multiple key transcription factors and functional genes of $\beta$ cells. The insulinotropic function of SB was attributed to increased insulin gene expression mediated by H3K18bu in its promoter region and elevated intracellular calcium concentration $\left(\left[\mathrm{Ca}^{2+}\right]_{i}\right)$ by ablating $\mathrm{K}_{\text {ATP }}$ channels.

\section{RESULTS}

SCFAs potentiates $\beta$ cell function while downregulating insulin secretion pathway

To determine the impact of SCFAs on islet $\beta$ cell function, isolated rat islets were treated with SA, SP, and SB. Consistent with previous reports [27], SCFAs were without acute effect on basal and glucose-induced insulin secretion (Fig. S1A). When the incubation time was prolonged to $24 \mathrm{~h}$, SCFAs significantly increased insulin secretion from rat islets at 3.3, 8.3, and $16.7 \mathrm{mM}$ glucose (Fig. 1A), without changing insulin content (Fig. S1B). At the concentration of $5 \mathrm{mM}$, SCFAs displayed no cytotoxicity on INS-1 cells (Fig. S1C). In addition, long-term treatment of SB further enhanced insulin secretion in the presence of cAMP-elevating agent forskolin (FSK), leucine and glutamine, and high potassium (Fig. 1B), without acute effects under the same conditions (Fig. S1D).

To understand the molecular basis underlying the insulinotropic action of SCFAs, the global gene expression patterns were analyzed by RNA-seq in rat islets incubated with or without SB for 24 h. 3266 differentially expressed genes (1967 upregulated and 1299 downregulated genes) were identified between SB group and control group (Fig. 1C) and subjected to KEGG pathway analysis. Interestingly, maturity-onset diabetes of the young (MODY) pathway including a series of $\beta$ cell key transcription factors and functional genes, was one of the most significantly downregulated pathways. The insulin secretion pathway was included in the top ten enriched KEGG pathways downregulated by SB (Fig. 1D), in contradiction with its insulinotropic effect. The key differentially expressed genes involved in insulin secretion from glucose metabolism to ion channel and insulin gene regulation were marked in Fig. $1 \mathrm{E}$.

\section{SB inhibits expressions of multiple $\beta$ cell identity genes}

We further presented a comprehensive assessment of the effects of SCFAs on the expression of genes related to $\beta$ cell functional maturity. The expressions of key $\beta$ cell functional genes Slc2a2, Gck, and Kcnj11, as well as key regulators of $\beta$ cell identity including Pdx1, MafA, Nkx2-2, Nkx6-1, and NeuroD1, were considerably decreased by SB treatment, while the expressions of insulin genes (Ins1 and Ins2) were increased (Fig. 2A). Similar effects of SB were observed in mouse islets (Fig. S2A). Furthermore, the expressions of Pdx1, MafA, NeuroD1, Slc2a2, Gck, and Kcnj11 were derepressed in INS-1 cells and mouse islets after SB was withdrawn, suggesting that the inhibitory effects of 

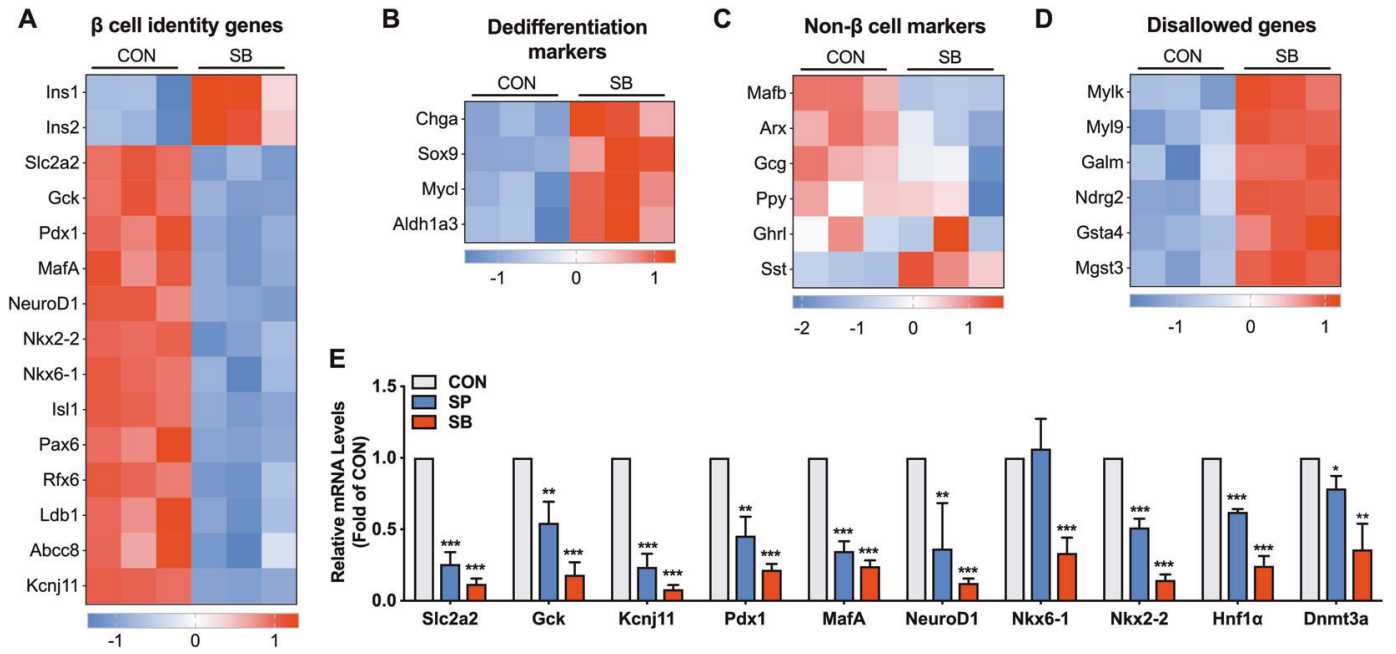

Fig. 2 Effects of sodium butyrate on the expression of $\boldsymbol{\beta}$ cell identity genes. A Heatmap of $\beta$ cell identity genes in control and sodium butyrate (SB)-treated rat islets. B Heatmap of dedifferentiation markers. C Heatmap of non- $\beta$ cell markers. D Heatmap of disallowed genes. E RT-qPCR analysis of $\beta$ cell identity genes in rat islets incubated with $5 \mathrm{mM}$ SP or $5 \mathrm{mM}$ sodium propionate (SB) for $24 \mathrm{~h}$. Data were given as mean \pm SD for three separate experiments. ${ }^{*} p<0.05,{ }^{* *} p<0.01$, and ${ }^{* * *} p<0.001$ vs control (CON) group.

SB were reversible (Fig. S2B, C). Given the previous reports $[3,9]$ that the loss of $\beta$ cell identity was usually accompanied with $\beta$ cell dedifferentiation and transdifferentiation, we then investigated the markers of the two processes. Aldh1a3, Chga, Sox9, and Mycl mRNA expressions were increased in SB-treated islets (Fig. 2B). Except for Sst, no other islet hormone genes such as Gcg, Ppy, and Ghrl exhibited significant increases in rat islets treated with SB (Fig. 2C).

The repression of disallowed genes is also crucial for proper $\beta$ cell mature phenotype [29]. Among 47 disallowed genes identified by Pullen et al. [30] and Thorrez et al. [31], six genes were upregulated in SB-treated islets (Fig. 2D). It has been reported that DNA and histone methylation is involved in the repression of disallowed genes [32]. Interestingly, the protein level of DNA methyltransferase 3a (Dnmt3a) displayed a significant decrease in SB-treated islets (Fig. S2D). Similar to the action of SB, SP also exerted inhibitory effects on the expression of $\beta$ cell identity genes in rat islets (Fig. 2E).

\section{Role of H3K27Ac in SB-modulated expression of $\beta$ cell identity genes}

$\mathrm{H} 3 \mathrm{~K} 27 \mathrm{Ac}$ has been regarded as a biomarker of cell type-specific promoters and enhancers involved in key cell identity gene expressions [8]. Therefore, we performed H3K27AC ChIPsequencing (ChIP-seq) analysis in SB-treated rat islets. A total of 13778 upregulated and 8828 downregulated H3K27Ac peaks were identified. Most upregulated or downregulated H3K27AC peaks were located in the intergenic and intron region (Fig. $3 A$ ). We further conducted an overlap analysis on H3K27Ac ChIP-seq data with RNA-seq data of SB-treated rat islets. As shown in Fig. 3B, ChIP-seq identified 3320 genes with reduced H3K27Ac peaks in one or more genetic regions, of which 258 genes were downregulated by SB at the mRNA level. Among 36 genes with hypoacetylation of $\mathrm{H} 3 \mathrm{~K} 27$ in their promoters, 11 genes exhibited decreased mRNA levels, with the highest proportion than those in other regions (Fig. 3C). In addition, 6668 genes were identified with elevated H3K27Ac level, of which 852 genes were upregulated by SB at the mRNA level (Fig. 3D). Among 647 genes with elevated $\mathrm{H} 3 \mathrm{~K} 27 \mathrm{Ac}$ level in their promoters, there were 186 genes upregulated by SB, showing the highest proportion than those in other regions (Fig. $3 \mathrm{E}$ ). These results indicate a strong correlation of H3K27Ac level in promoter with gene transcription. We further performed KEGG pathway analysis on the overlapping 186 genes. Fatty acid degradation pathway and tryptophan metabolism pathway were significantly enriched (Fig. 3F). However, the level of H3K27Ac showed no significant changes in the promoter regions of Ins1, Slc2a2, Pdx1, and $\mathrm{Nkx2}-2$ after SB treatment (Fig. 3G, H). These findings suggest that other alternative mechanisms are involved in SB-mediated expressions of $\beta$ cell identity genes.

\section{SB represses $\beta$ cell identity genes independent of its deacetylase activity}

To further explore the molecular mechanism of SB, the prediction of upstream regulator was performed using Ingenuity Pathway Analysis (IPA) based on all differentially expressed genes. HDAC was predicted to be inhibited while four HDAC inhibitors butyric acid, trichostatin A (TSA), romidepsin, and vorinostat were predicted to be activated (Fig. 4A), suggesting involvement of acetylation in SB-mediated changes of $\beta$ cell transcriptome. Like two HDAC inhibitors MS-275 and TSA, three SCFAs significantly increased the acetylation levels of histone $\mathrm{H} 3$ and $\mathrm{H} 2$ in INS- 1 cells (Fig. S2E). We performed an overlapping analysis on two sets of gene expression profiles between SBand TSA-treated rat islets. There were 844 differentially expressed genes consistently regulated by SB and TSA (Fig. $4 B)$. Among these genes, Aldh2, Acadm, Gcdh, and Tph1 were upregulated by both SB and TSA (Fig. 4C) while Dis3l, Zbed3, and Aars 1 were downregulated by the two agents (Fig. 4D). H3K27Ac levels in the promoters of these genes displayed a corresponding change in the presence of SB except for Tph1 (Fig. 4E, F), suggesting involvement of acetylation in the regulation of gene expression. However, unlike in SB-treated islets, the key $\beta$ cell functional genes and identity genes such as Slc2a2, Gck, Pdx1, NeuroD1, Nkx6-1, Ins1, and Ins2 showed no significant changes in TSA-treated islets except for Konj11 (Fig. S3). These results further indicate that there exists a nonacetylation mechanism involved in SB-mediated regulation of islet $\beta$ cell identity genes.

\section{SB-potentiated insulin secretion is independent of glucose oxidation in rat islets}

GSIS is usually linked to increased glucose metabolism through glycolysis and oxidation to generate ATP. The glucose flux into $\beta$ cell is mainly determined by glucose transporter, Glut2 (encoded by Slc2a2) and glucokinase (encoded by Gck) [1]. Interestingly, Slc2a2 and Gck mRNA expressions exhibited a significant decrease in rat islets treated with SB or SP (Fig. 5A), contrary to the potentiated 

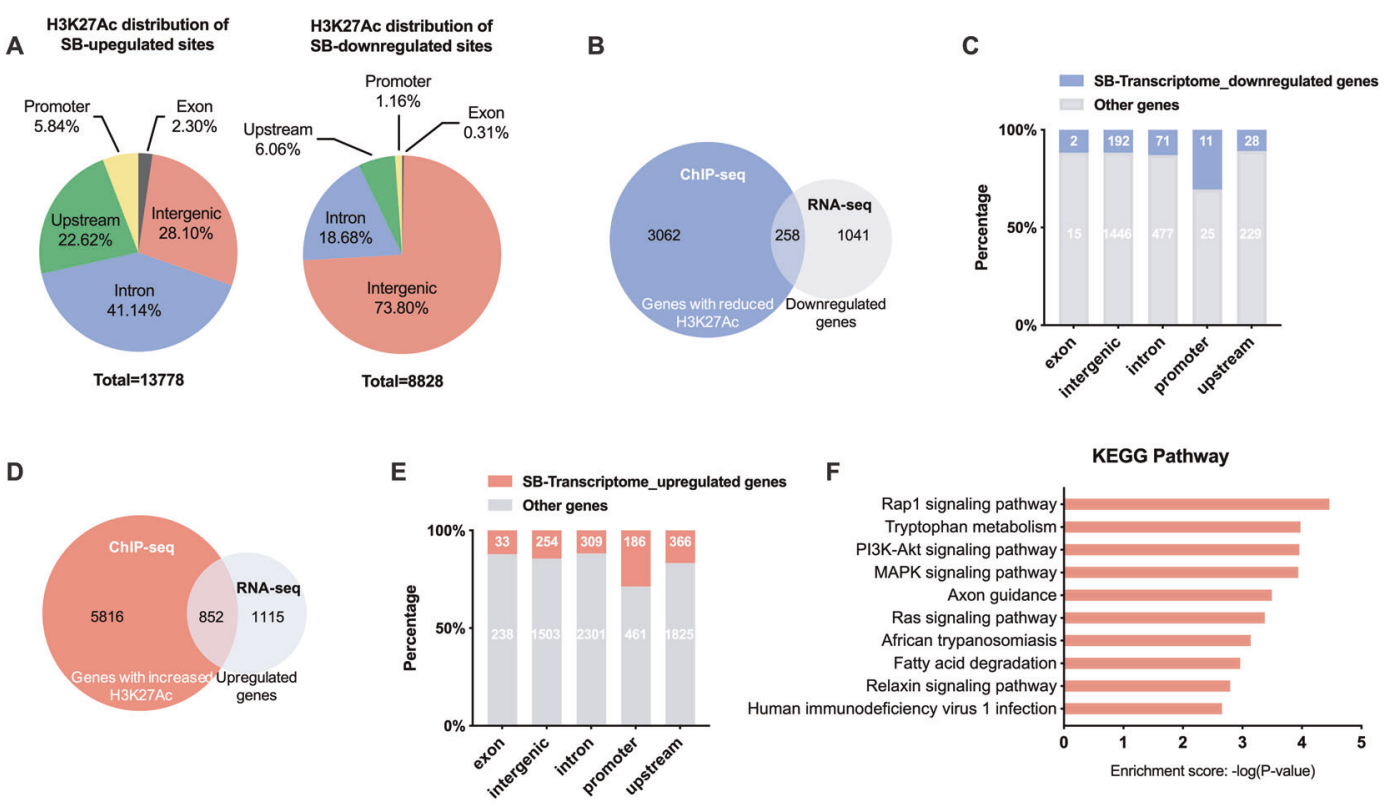

G

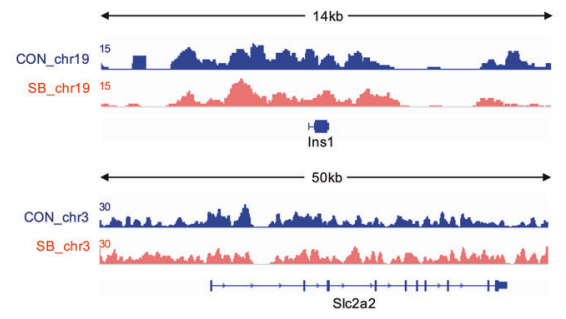

H

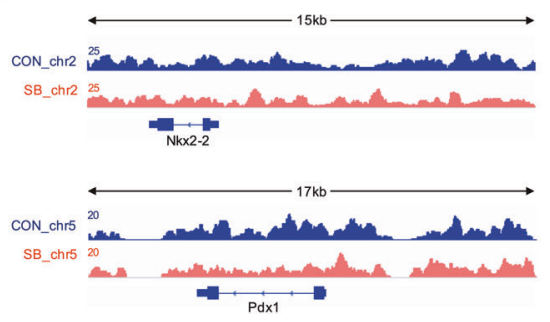

Fig. 3 Role of H3K27Ac in sodium butyrate-induced changes of gene expressions shown by ChIP-seq analysis. A Genomic distribution of H3K27Ac enriched peaks regulated by sodium butyrate (SB) (fold change $>2.0$, $p$-value $<0.001$ ). B Venn diagram of the overlap between annotated genes with downregulated H3K27Ac occupation and downregulated genes identified in RNA-seq. C Genomic distribution of both H3K27Ac enriched peaks and corresponding genes downregulated by SB (blue). D Venn diagram of the overlap between annotated genes with upregulated H3K27Ac occupation and upregulated genes identified in RNA-seq. E Genomic distribution of both H3K27Ac enriched peaks and corresponding genes upregulated by SB (orange). F KEGG pathway analysis on the overlapping upregulated genes by SB at mRNA level and H3K27Ac level in their promoter. G, H Detailed H3K27Ac patterns of Ins1, Slc2a2, Nkx2-2, and Pdx1 from ChIP-Seq. Gene structure and chromosomal location are shown.

GSIS (Fig. 1A). We further measured oxygen consumption rate $(\mathrm{OCR})$ in rat islets in response to glucose as an indicator of glucose oxidation with Seahorse XF24 analyzers. Basal OCR in rat islets incubated with $3.3 \mathrm{mM}$ glucose was elevated by acute SB treatment. However, with elevated concentration of glucose, the difference of OCR between SB-treated and control islets disappeared (Fig. 5B). Glucose-stimulated OCR was significantly decreased in SB-treated rat islets compared with control islets (Fig. 5C). This was the case in rat islets pretreated with SB for $24 \mathrm{~h}$ (Fig. 5D, E). To further investigate the effect of SB on mitochondria respiration, we performed mitochondria stress assay in rat islets as shown in Fig. 5F. The initial OCR was evaluated to establish the basal respiration, the ATP-coupled OCR was determined following injection of the complex $\mathrm{V}$ inhibitor oligomycin, and the maximal respiration was evaluated upon addition of the uncoupling agent FCCP. SB pretreatment elevated mitochondrial basal OCR, but without effect on ATP-coupled and maximal respiration rates (Fig. $5 G)$. The abundance of mitochondrial DNA was increased by SB (Fig. $5 \mathrm{H}$ ). No obvious changes were observed in the levels of mitochondrial proteins SDHA and ATP5A1 between SB-treated and control islets (Fig. 5l). The mRNA levels of genes encoding enzymes critical for glycolysis, tricarboxylic acid (TCA) cycle, and oxidative phosphorylation showed no significant changes in SB-treated islets (Fig. S4A, B). These results indicate that SB-potentiated insulin secretion is independent of glucose oxidation.

\section{SB inhibits the expression of $\mathrm{K}_{\mathrm{ATP}}$ and increases $\left[\mathrm{Ca}^{2+}\right]_{i}$ in islet $\boldsymbol{\beta}$ cells}

$\mathrm{K}_{\mathrm{ATP}}$ channels are essential for the process of stimulus-secretion coupling. $\mathrm{K}_{\text {ATP }}$ channels in $\beta$ cell are composed of pore-forming Kir6.2 (encoded by Kcnj11) and regulatory SUR subunit (encoded by Abcc8) [33]. RNA-seq data showed that SB suppressed Kcnj11 mRNA expression in rat islets. RT-qPCR further confirmed that both SB and SP, not SA obviously decreased Kcnj11 mRNA expression in INS-1 cells (Fig. 6A). Kcnj11 protein expression exhibited a similar result (Fig. 6B). Surprisingly, the mRNA level of Kcnj11 decreased by $90 \%$ just $2 \mathrm{~h}$ after SB treatment (Fig. $6 \mathrm{C}$ ). Kcnj11 protein expression was gradually attenuated with the prolonged incubation of $\mathrm{SB}$, with the most profound action at $24 \mathrm{~h}$ (Fig. 6D). Considering the link of $\mathrm{K}_{\text {ATP }}$ channels to intracellular calcium concentration, we measured $\left[\mathrm{Ca}^{2+}\right]_{i}$ in SB-pretreated rat islet $\beta$ cells using patch clamp. As expected, the level of $\left[\mathrm{Ca}^{2+}\right]_{\mathrm{i}}$ at $3.3 \mathrm{mM}$ glucose was relatively low and was significantly elevated by $16.7 \mathrm{mM}$ glucose in the control group. In SB-pretreated $\beta$ cells, the level of $\left[\mathrm{Ca}^{2+}\right]_{i}$ at $3.3 \mathrm{mM}$ glucose was near to the level triggered by high glucose in control $\beta$ cells, not further raised by the addition of glucose (Fig. 6E). The basal level of $\left[\mathrm{Ca}^{2+}\right]_{i}$ in SB-pretreated $\beta$ cells was markedly higher compared with control $\beta$ cells while high glucose-elicited $\left[\mathrm{Ca}^{2+}\right]_{\mathrm{i}}$ was considerably lower (Fig. 6F, G). Apparently, the lack of $\mathrm{K}_{\text {ATP }}$ channels induced by SB treatment 
A

\begin{tabular}{|c|c|c|c|}
\hline $\begin{array}{c}\text { Upstream } \\
\text { Regulator }\end{array}$ & $\begin{array}{c}\text { Predicted } \\
\text { Activation } \\
\text { State }\end{array}$ & $\begin{array}{c}\text { Activation } \\
\text { z-score }\end{array}$ & $\begin{array}{c}p \text {-value of } \\
\text { overlap }\end{array}$ \\
\hline Hdac & Inhibited & -3.285 & $5.55 \mathrm{E}-06$ \\
\hline butyric acid & Activated & 4.002 & $5.57 \mathrm{E}-09$ \\
\hline trichostatin A & Activated & 3.007 & $1.16 \mathrm{E}-05$ \\
\hline romidepsin & Activated & 2.454 & $7.49 \mathrm{E}-05$ \\
\hline vorinostat & Activated & 2.139 & $3.48 \mathrm{E}-03$ \\
\hline
\end{tabular}

C

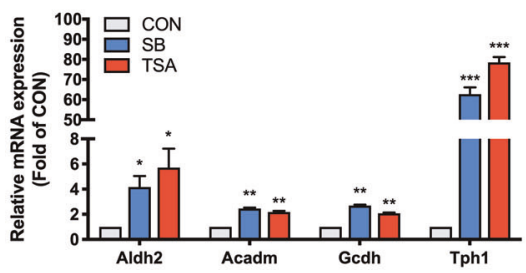

E
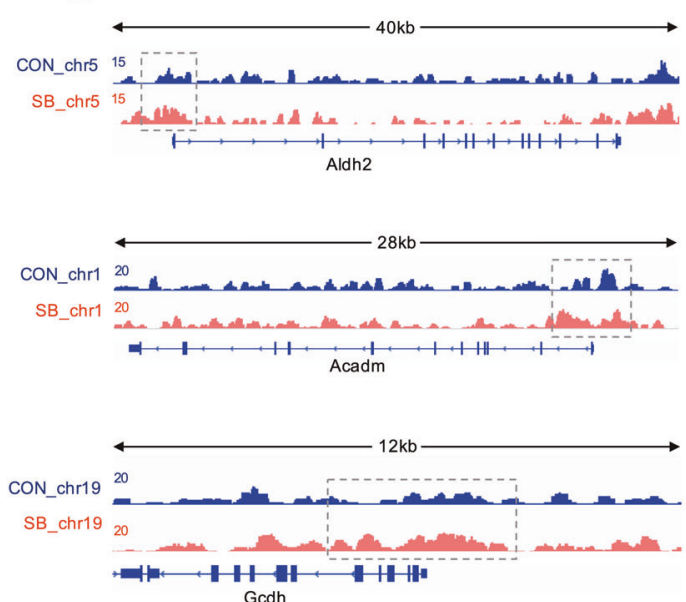

B

Differentially-expressed genes

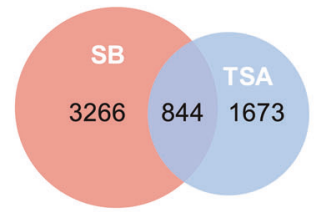

D

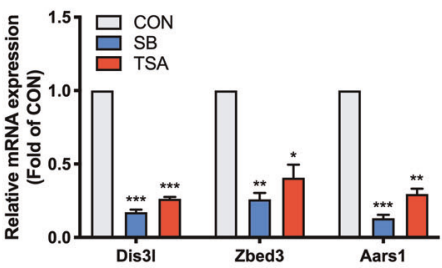

$\mathbf{F}$
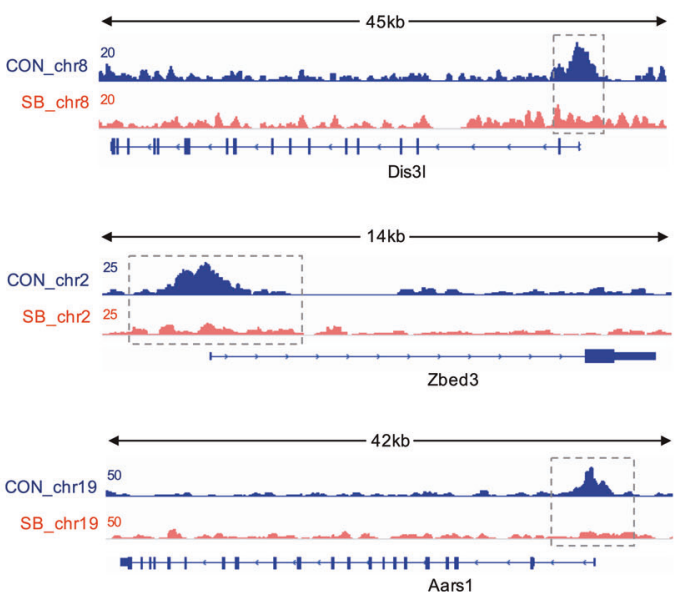

Fig. 4 Comparative analysis of the gene expression profiles from sodium butyrate- and trichostatin A-treated rat islets. A Upstream regulator analysis of Ingenuity Pathway Analysis (IPA) on sodium butyrate (SB)-regulated genes. B Overlapping differentially expressed genes in rat islets regulated by both SB and trichostatin A (TSA). C, D RT-qPCR analysis of commonly upregulated and downregulated genes in rat islets by $5 \mathrm{mM}$ SB and $200 \mathrm{nM}$ TSA. E H3K27Ac patterns of Aldh2, Acadm, and Gcdh from ChIP-seq. Gene structure and chromosomal location are shown, with the gray dotted box highlighting the upregulated peaks in their promoter regions by SB. F H3K27Ac patterns of Dis3l, Zbed3, and Aars1 from ChIP-Seq. Gene structure and chromosomal location are shown, with the gray dotted box highlighting the downregulated peaks in their promoter regions by SB. Data were given as mean \pm SD for three separate experiments. ${ }^{*} p<0.05,{ }^{* *} p<0.01,{ }^{* * *} p<0.001$ vs control (CON) group.

triggers continuous depolarization of the $\beta$ cell membrane, leading to $\mathrm{Ca}^{2+}$ influx and exocytosis of insulin secretory granules.

\section{H3K18bu occupation in insulin gene promoter is involved in SB-stimulated insulin gene expression}

In accordance with RNA-seq data, RT-qPCR validated the upregulation of Ins1 and Ins2 expression in rat islets treated with $\mathrm{SB}$ at $3.3 \mathrm{mM}$ glucose, not at 8.3 and $16.7 \mathrm{mM}$ glucose (Fig. 7A, B). It is widely recognized that the insulin gene expression is governed by three transcription factors Pdx1, MafA, and NeuroD1 [34-36]. However, SB significantly decreased the protein levels of the three key transcription factors (Fig. 7C), excluding their involvement in SB-induced insulin gene expression. It has been reported that rat insulin promoter contains an active CAMPresponsive element (CRE) [37]. Indeed, SB-induced Ins1 and Ins2 gene expressions were abolished by H89, a PKA inhibitor (Fig. 7D). However, the phosphorylation of CREB was not stimulated by SB (Fig. 7E). Recently, increasing evidence has shown that beyond acetylation, other lysine acylation modifications such as butyrylation and succinylation are involved in gene expression regulation $[38,39]$. The substrates for these modifications, such as butyryl-CoA and succinyl-CoA are derived from metabolic intermediates of glucose, fatty acid, or other nutrients. SB could be metabolized to butyryl-CoA [40]. As expected, an obvious increase in total histone butyrylation level was observed in SB-treated INS1 cells (Fig. 7F). Furthermore, ChIP-qPCR result showed that SB increased H3K18bu levels in the promoter regions of Ins1 and Ins2 (Fig. 7G). Therefore, it is likely that SB increases H3K18bu levels to promote chromosome opening, leading to an increase in insulin gene expression.

\section{DISCUSSION}

It is generally accepted that SCFAs generated by gut microbiota exert a beneficial impact on energy metabolism via central mechanisms and peripheral actions [18]. The role of SCFAs in islet function should be paid more attention as insulin is the central regulator of metabolism. However, there exist contradictory results about their action in this aspect [41]. The present study 
A

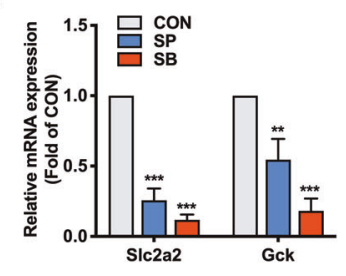

D

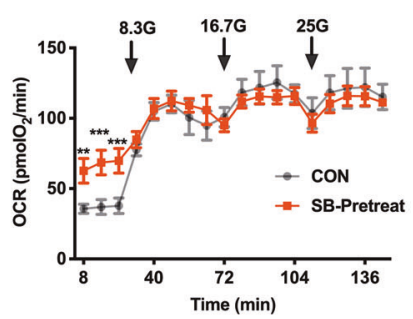

G

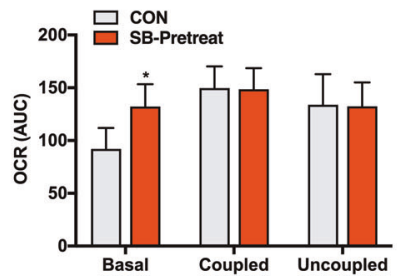

B
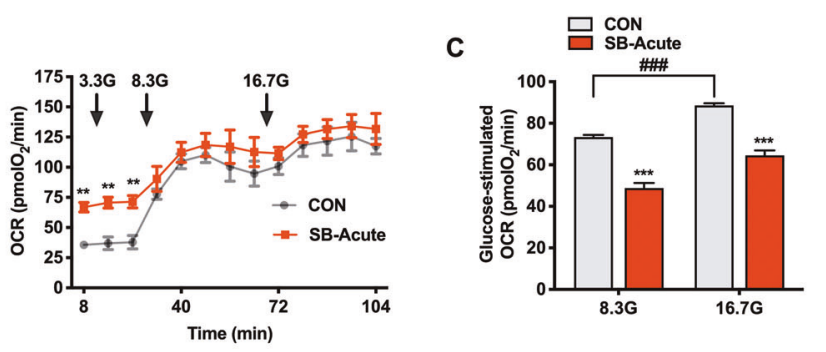

E

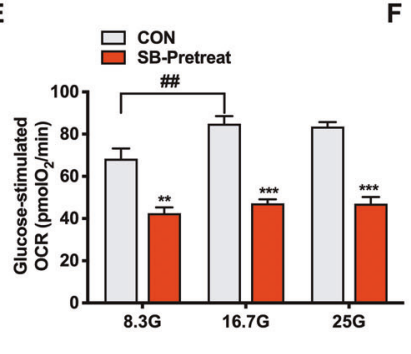

H

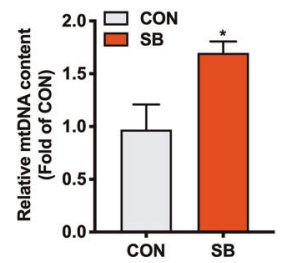

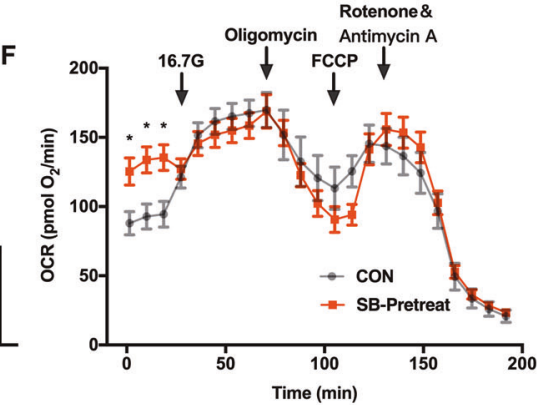

I

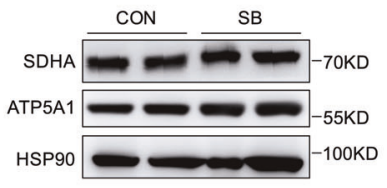

Fig. 5 Sodium butyrate treatment decreases glucose oxidation in rat islets. A RT-qPCR analysis of SIc2a2 and Gck mRNA expressions in rat islets incubated with $5 \mathrm{mM}$ sodium butyrate (SP) or $5 \mathrm{mM}$ sodium propionate (SB) for $24 \mathrm{~h}$. B Basal and glucose-stimulated oxygen consumption rate (OCR) in rat islets treated with $5 \mathrm{mM}$ SB for $1 \mathrm{~h}$. C Determination of glucose-stimulated OCR based on B. D Basal and glucose-stimulated OCR in rat islets treated with $5 \mathrm{mM}$ SB for $24 \mathrm{~h}$. E Determination of glucose-stimulated OCR based on D. F After rat islets were treated with $5 \mathrm{mM}$ SB for $24 \mathrm{~h}$, OCR was measured in the presence of $25 \mathrm{mM}$ glucose, $1 \mu \mathrm{M}$ oligomycin, $2 \mu \mathrm{M} \mathrm{FCCP}$, or $0.5 \mu \mathrm{M}$ rotenone/ antimycin $A$ at the indicated time points (arrows). G Determination of basal, coupled, and uncoupled respiration in F. $\mathbf{H}$ mtDNA content in INS1 cells treated with $5 \mathrm{mM}$ SB for $24 \mathrm{~h}$. I SDHA (Complex II) and ATP5A1 (Complex V) protein expressions in INS-1 cells treated with $5 \mathrm{mM}$ SB for $24 \mathrm{~h}$. Data were given as mean \pm SD for three separate experiments. ${ }^{*} p<0.05,{ }^{* *} p<0.01,{ }^{* *} p<0.001$ vs control (CON) group. \#\#p<0.01, $\# \# \# p<0.001$.

revealed a strong insulinotropic function of SCFAs after a longterm incubation. Surprisingly, SB treatment led to an unusual transcriptome change, with downregulation of multiple $\beta$ cell identity genes. In addition, it seemed to be conflicting that enhanced GSIS was accompanied with reduced glucosestimulated OCR in rat islets treated with SB. Our study further demonstrated that SB enhanced insulin gene expression through increasing $\mathrm{H} 3 \mathrm{~K} 18 \mathrm{bu}$ occupation in its promoter and potentiated insulin secretion via elevating $\left[\mathrm{Ca}^{2+}\right]_{\mathrm{i}}$ mediated by the ablation of $\mathrm{K}_{\text {ATP }}$ channels, uncovering a novel mechanism underlying the potentiation of islet function independent of key $\beta$ cell transcription factors and functional genes.

It has been well established that fatty acids are essential for insulin secretion. Acute lowering of plasma fatty acid level decreased the basal and glucose-induced insulin secretion $[12,42]$. On the contrary, the elevation of fatty acid level significantly enhanced GSIS in vitro and in vivo $[43,44]$. The potency of fatty acid to promote insulin secretion was subjected to chain length and degree of saturation [14]. Long-chain fatty acid palmitate and medium-chain FA octanoic acid potentiate acute insulin secretion at basal and high glucose concentrations $[45,46]$. SCFAs acetate, propionate, and butyrate improve glucose tolerance, insulin sensitivity, and body weight [18]. The in vivo beneficial impact of SCFAs on $\beta$ cell function is attributed to the elevation of GLP-1. However, the direct effect of SCFAs on insulin secretion remains controversial $[47,48]$. There are reports that
SCFAs exhibit inhibitory, stimulating, or no acute effect on insulin secretion [41]. Little is known about the long-term impact of SCFAs on islet $\beta$ cell function. In this current study, none of the three SCFAs displayed acute effects on basal and glucose-induced insulin secretion. However, the pretreatment of SA, SP or SB for $24 \mathrm{~h}$ significantly amplified insulin secretion from isolated rat islets in response to various stimuli. Moreover, the insulinotropic effect increased with the chain length, with SB showing the most profound effect.

Histone acetylation loosens the chromatin structure and promotes gene transcription whereas histone deacetylation exerts a contrary action. It has been reported that HDACs are expressed in the pancreas [49] and are involved in the development, differentiation, proliferation, and function of islet $\beta$ cells [50]. H3K27ac was previously revealed to be associated with both active promoters and enhancers in human islet cells [51] and in mouse islets [52]. In the present study, the analysis of RNA-seq and H3K27Ac ChIP-seq supported that SB-induced transcriptome change was partially dependent on its role as an HDAC inhibitor. Several genes involved in the metabolism pathway, such as Aldh2 and Acadm were upregulated by $\mathrm{SB}$ as their promoter regions displayed hyperacetylation of H3K27. Unusually, SB selectively inhibited the expressions of multiple $\beta$ cell identity genes. However, their expressions barely showed any changes in TSAtreated islets. Nor did the H3K27Ac peaks in the promoter of these 
A

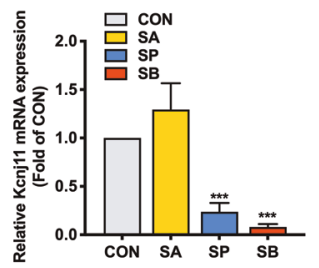

c
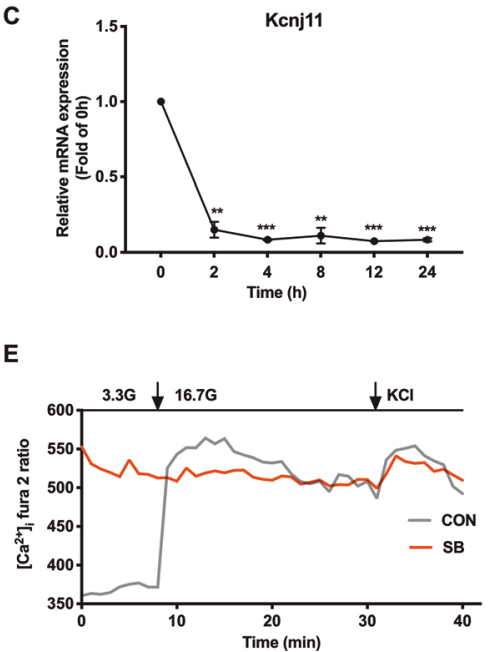

B

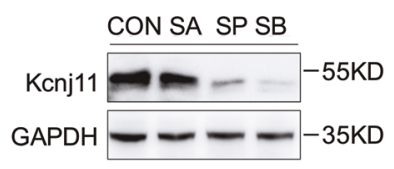

D

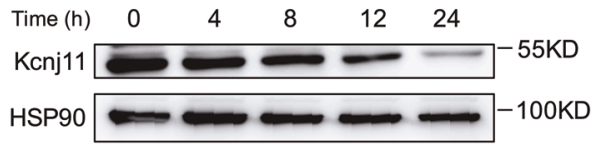

F

G
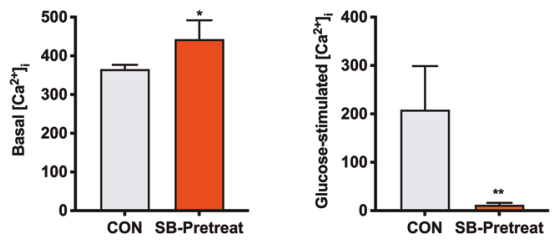

Fig. 6 Sodium butyrate inhibits the expression of $\mathrm{Kcnj11}$ and increases $\left[\mathrm{Ca}^{2+}\right]_{i}$ in rat islet $\boldsymbol{\beta}$ cells. A, B Kcnj11 mRNA and protein expressions in rat islets treated with $5 \mathrm{mM}$ sodium acetate (SA), $5 \mathrm{mM}$ sodium propionate (SP), and $5 \mathrm{mM}$ sodium butyrate (SB) for $24 \mathrm{~h}$. C, D Kcnj11 mRNA and protein expressions in INS-1 cells treated with $5 \mathrm{mM}$ SB for the indicated time. E Dispersed rat islet cells were incubated with $5 \mathrm{mM} \mathrm{SB}$ for $24 \mathrm{~h}$ and intracellular $\mathrm{Ca}^{2+}$ concentration $\left(\left[\mathrm{Ca}^{2+}\right]_{\mathrm{i}}\right)$ was measured by patch-clamp technique. $\mathbf{F}$ Determination of basal $\left[\mathrm{Ca}^{2+}\right]_{\mathrm{i}}$ in E. G The increase of glucose-stimulated $\left[\mathrm{Ca}^{2+}\right]_{\mathrm{i}}$ in $\mathbf{E}$. Data were given as mean \pm SD for three separate experiments. ${ }^{*} p<0.05,{ }^{* *} p<0.01$, ${ }^{* * *} p<0.001$ vs basal or control (CON) group.

genes in SB-treated islets. These results suggest that the inhibitory effect of SB on $\beta$ cell identity genes is independent of its deacetylation action.

The magnitude of GSIS is tightly linked to the rate of glucose metabolism mediated by the permissive rates of glucose uptake and phosphorylation. Glucose transport into $\beta$ cell is mediated by transporters Glut1 in humans or Glut2 in rodents [1]. Following the entry into the $\beta$ cell, glucose is rapidly phosphorylated by Gck, a rate-limiting enzyme. and then metabolized through glycolytic and oxidative pathways. Glut 2 and Gck have been considered as the "glucose sensors" in $\beta$ cells [53]. Mutations in the human GCK gene lead to monogenic diabetes (MODY2) [54]. In this current study, Slc2a2 and Gck mRNA expressions were significantly attenuated in INS-1 cells and rat islets in exposure to SB. Considering the central role of Glut2 and Gck in glucose metabolism, it is reasonable to suppose that the glucose flux into $\beta$ cell is decreased in SB-treated islets. As expected, glucosestimulated oxidation was significantly reduced by SB treatment, but the genes involved in glycolysis and TCA barely showed any changes. Moreover, no obvious alterations in mitochondrial function were observed in SB-treated rat islets. These results indicate that the reduction of glucose oxidation induced by SB is due to the decreased glucose flux into $\beta$ cells. It seems strange that glucose-induced insulin secretion is decoupled with its metabolism in rat islets treated with SB. Apparently, SBrepressed Kcnj11 expression and subsequent increased $\left[\mathrm{Ca}^{2+}\right]_{i}$ could partially address its insulinotropic action.

The sustained proinsulin biosynthesis ensures sufficient insulin content for secretion, which is tightly regulated at the transcription level. Glucose is a key regulator of insulin gene transcription [55]. It has been demonstrated that three $\beta$ cell-specific transcription factors Pdx1, NeuroD1, and MafA play a crucial role in glucose- regulated insulin gene transcription and $\beta$ cell function [34-36]. Moreover, mutations in the human Pdx1 and NeuroD1 genes lead to MODY4 and MODY6, respectively. In addition, there also exists a CRE in the promoter of rat Ins1 and Ins2 genes [56]. CAMP analogs have been shown to increase insulin mRNA levels in rat and human islets via stimulating CREB phosphorylation and its binding with $\mathrm{CRE}$ in the promoter of the insulin gene. Deletion or mutagenesis of this sequence abolished the CAMP stimulatory effect [56]. In addition to transcription factors, an open chromosome structure mediated by histone modification is also indispensable to induce transcriptional activation. It was reported that high glucose promoted histone acetylation in the promoter of the insulin gene and elicited insulin gene transcription in MIN-6 cells [57]. SB increased insulin gene expression and $\beta$ cell function in the islets of juvenile diabetic rats [58] and the rat insulinoma $\beta$ cell line RIN 1046-38 [59]. In our study, the mRNA levels of rat Ins1 and Ins2 genes were increased in rat islets treated with SB while Pdx1, MafA, and NeuroD1 displayed significant decreases at mRNA and protein levels. The phosphorylation of CREB was not stimulated by SB. Additionally, unlike SB, TSA did not induce insulin gene expression, indicating involvement of other mechanisms in SB-triggered insulin transcription. Besides acetylation, histone butyrylation could also directly stimulate gene transcriptional activity [60]. In the liver, H3K18bu was downregulated by a high-fat diet [61]. In our study, SB treatment increased the H3K18bu level in the promoters of Ins 1 and Ins2 genes. It is likely that SB stimulates insulin gene transcription through increasing the H3K18bu level.

In summary, it is an interesting finding that SB treatment enhances insulin secretion from rat islets while downregulating a set of $\beta$ cell identity genes. Apparently, SB-repressed $\beta$ cell key functional genes and transcription factors are independent of its deacetylase activity. SB-potentiated $\beta$ cell function is attributed to 
A

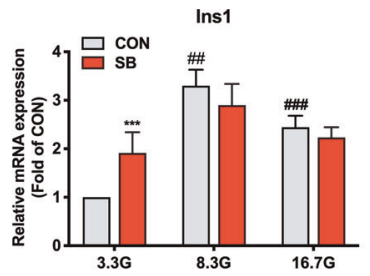

B

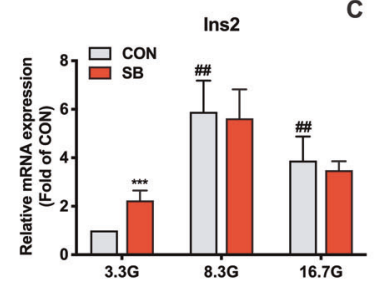

C
D

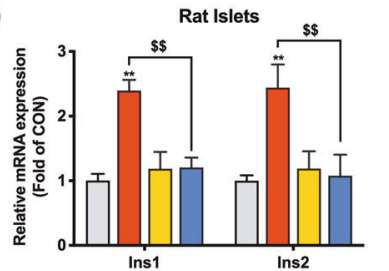

G

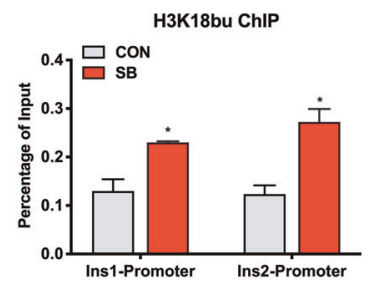

E

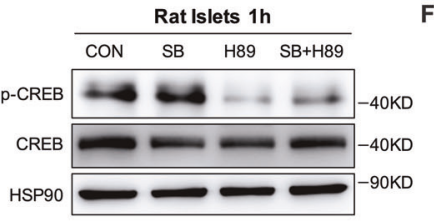

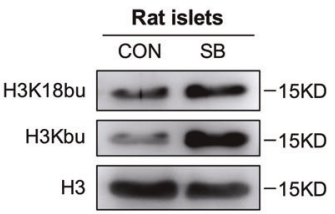

H

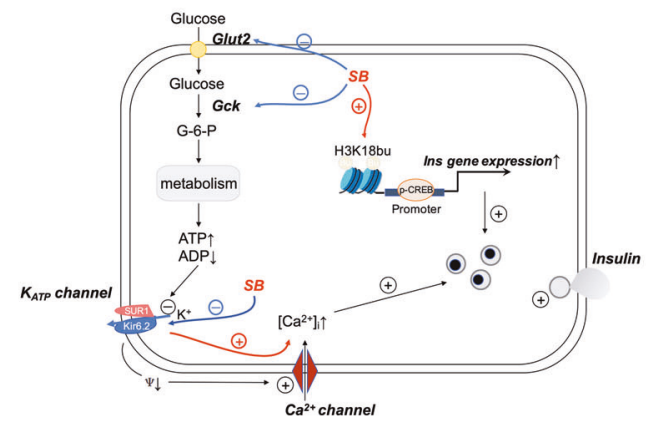

Fig. 7 Sodium butyrate increases H3K18bu occupation in insulin gene promoter. A, B Ins1 and Ins2 mRNA expressions in rat islets treated with $5 \mathrm{mM}$ sodium butyrate (SB) at 3.3, 8.3, or $16.7 \mathrm{mM}$ glucose for $24 \mathrm{~h}$ measured by RT-qPCR. C Pdx1, MafA, and NeuroD1 protein expressions in rat islets treated with $5 \mathrm{mM} \mathrm{SB}$ at 3.3, 8.3, or $16.7 \mathrm{mM}$ glucose for $24 \mathrm{~h}$. D Ins1 and Ins2 mRNA expressions in rat islets incubated with $5 \mathrm{mM}$ $\mathrm{SB}$ and $10 \mu \mathrm{M} \mathrm{H} 89$ for $24 \mathrm{~h}$. E CREB phosphorylation level in rat islets incubated with $5 \mathrm{mM}$ SB and $10 \mu \mathrm{M} \mathrm{H} 89$ for $1 \mathrm{~h}$. F Global histone butylation and H3K18 butylation levels in rat islets treated with $5 \mathrm{mM}$ SB for $8 \mathrm{~h}$. G H3K18bu levels at the promoter region of Ins1 and Ins2 gene detected by ChIP-qPCR. $\mathbf{H}$ The schematic illustration summarizes the effect of SB on $\beta$ cell function. Data were given as mean \pm SD for

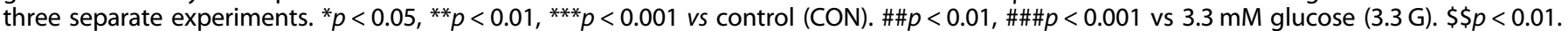

the elevated $\left[\mathrm{Ca}^{2+}\right]_{i}$ via decreasing $\mathrm{K}_{\mathrm{ATP}}$ channels and increased insulin gene transcription due to H3K27bu occupation in its promoter, independent of glucose oxidation. Our work indicates a unique mechanism by which SB potentiates insulin secretion at the expense of compromised islet $\beta$ cell identity gene expressions.

\section{METHODS}

\section{Islet isolation, cell culture, and treatment}

Pancreatic islets were isolated from 8- to 10-week-old wild-type SpragueDawley (SD) male rats by collagenase digestion and density-gradient centrifugation. INS-1 cells were cultured in RPMI 1640 medium with $11.1 \mathrm{mM}$ glucose that contained 10\% FBS, $10 \mathrm{mM}$ HEPES, $1 \%$ penicillin/ streptomycin, $1 \mathrm{mM}$ sodium pyruvate, and $50 \mu \mathrm{M}$ beta-mercaptoethanol. Plasmid transfection was performed with Lipofectamine 3000 (Invitrogen). SA, SP, and SB were purchased from Sigma-Aldrich.

\section{Insulin secretion assay}

Isolated islets were pre-incubated in Krebs-Ringer Buffer (KRB) containing $3.3 \mathrm{mM}$ glucose at $37^{\circ} \mathrm{C}$ for $30 \mathrm{~min}$. Ten islets per assay in triplicate were then incubated with KRB buffer containing other additions as indicated for $1 \mathrm{~h}$ at $37^{\circ} \mathrm{C}$. The supernatant was collected for insulin secretion analysis, and islets were then extracted with acid-ethanol to determine total insulin content. Insulin levels were estimated using an ELISA kit (Mercodia, St Charles, MO).

\section{RNA sequencing analysis}

Isolated rat islets were cultured in RPMI 1640 medium with $3.3 \mathrm{mM}$ glucose and $0.25 \%$ BSA in the presence or absence of $5 \mathrm{mM} \mathrm{SB}$ for $24 \mathrm{~h} .1 \mu \mathrm{g}$ total
RNA was used to prepare RNA-seq libraries by the KAPA Stranded RNA-Seq Library Prep Kit (Illumina), and then deep sequencing was performed with an Illumina HiSeq 4000 by KangChen Biotech Company (Shanghai, China). RNA-seq reads were compared to Rattus norvegicus genome. The differentially expressed genes and transcripts were identified by setting a threshold at fold change $>2.0, p$-value $<0.001$.

\section{ChIP-seq}

Isolated rat islets incubated with or without $5 \mathrm{mM} \mathrm{SB}$ for $24 \mathrm{~h}$ were crosslinked with $1 \%$ formaldehyde, lysed, and sonicated to shear the chromatin into appropriate fragments. Immunoprecipitation was performed with the H3K27Ac antibody (Millipore). TruSeq Nano DNA Sample Prep Kit (Illumina) was used for sequencing library preparation. Sequencing was performed on Illumina HiSeq 4000 using HiSeq 3000/4000 SBS Kit for 300 cycles. MACS v1.4.2 (Model-based Analysis of ChIP-seq) software was run with the mapped reads to detect the statistically significant ChIPenriched peaks compared with the respective input group by a $p$-value threshold of $10^{-4}$. All regions were annotated by the gene whose TSS was nearest to the center of the peak region according to the newest UCSC RefSeq database and divided into five classes based on the distance to UCSC RefSeq genes. Coverage, reads, and peaks were visualized with Integrative Genomics Viewer (IGV).

\section{Microarray expression analysis}

Total RNA was extracted from isolated rat islets treated with or without $200 \mathrm{nM}$ TSA for $24 \mathrm{~h}$ using Trizol (Invitrogen). Sample labeling and array hybridization were performed according to the instructions for the Agilent One-Color Microarray-Based Gene Expression Analysis protocol (Agilent Technologies, Inc., Santa Clara, CA, USA). Labeled CRNAs were hybridized onto the Whole Genome Oligo Array ( $4 \times 44 \mathrm{~K}$; Agilent Technologies) and 
the arrays were scanned by the Agilent Scanner G2505C. Agilent Feature Extraction software (version 11.0.1.1) was used to analyze acquired array images.

\section{RNA isolation and RT-qPCR}

Total RNA was extracted using RNeasy Plus Mini Kit (including a DNase digestion step, Qiagen $\mathrm{GmbH}$, Germany) from islets and the first strand of CDNA was synthesized using the reverse transcription kit (Toyobo Co., Ltd., Osaka, Japan). RT-qPCR was performed using Applied Biosystems 7300 Real-Time PCR machine (Applied Biosystems, Foster City, CA, USA) and the reagent SYBR Premix Ex Taq II (Takara, Shiga, Japan). The relative mRNA expression level of each gene was normalized to that of $18 \mathrm{~S}$ or $\beta$-actin. The primer sequences were described in Supplemental Table 1.

\section{Western blot}

Isolated rat islets or INS-1 cells were treated with RIPA lysis buffer for total protein extraction. Blotted membrane was imaged with a LAS-4000 Super CCD remote control science imaging system (Fuji). Antibody information was listed in Supplemental Table 2.

\section{Chromatin immunoprecipitation (ChIP)}

The ChIP assay was performed using an EZ-ChIP Chromatin Immunoprecipitation kit (EMD Millipore, Billerica, MA, USA) according to the manufacturer's protocol. In brief, rat islet cells were fixed using the formaldehyde with $1 \%$ formaldehyde and homogenized in cell lysis buffer. DNA was sheared to fragments at $200-1000 \mathrm{bp}$ using sonication. Chromatins were incubated and precipitated with antibody against H3K18bu or IgG (both from PTM Biolabs). DNA pellets were analyzed by real-time GPCR by using primers directed to the Ins1 promoter and Ins2 promoter (Supplemental Table 1).

\section{$\left[\mathrm{Ca}^{2+}\right]_{\mathrm{i}}$ recording in single islet $\beta$ cells}

$\left[\mathrm{Ca}^{2+}\right]_{\mathrm{i}}$ was measured by placing the coverslip on the stage of IX71 inverted microscope (Olympus). The single islet cells were loaded with $4 \mu \mathrm{M}$ Fura 2-AM (Sigma) for $30 \mathrm{~min}$ at $37^{\circ} \mathrm{C}$ in KRBB containing $3 \mathrm{mM}$ glucose, then washed with KRBB, and stimulated with $16.7 \mathrm{mM}$ glucose or $35 \mathrm{mM} \mathrm{KCl}$. The single cells were illuminated by excitation at $340 \mathrm{~nm}$ (F340) and $380 \mathrm{~nm}$ (F380) using a monochromator (Till Photonics, Munich, Germany), and the emission signals were detected at $510 \mathrm{~nm}$ using an image-intensifying CCD camera (SensiCam, PCO, Kelheim, Germany). The images were collected at $10 \mathrm{~s}$ intervals. The $\left[\mathrm{Ca}^{2+}\right]_{\mathrm{i}}$ was expressed as the ratio of F340/F380 (AU).

\section{Oxygen consumption rate measurement}

Isolated rat islets were pretreated with $5 \mathrm{mM} \mathrm{SB}$ for $24 \mathrm{~h}$, then the oxygen consumption rate of isolated islets was measured using a Seahorse XF24 flux analyzer (Seahorse Bioscience) according to the manufacturer's instructions. In brief, for glucose oxidation assay, 8.3, 16.7, or $25 \mathrm{mM}$ glucose was added to stimulate cellular oxygen consumption. For the mitochondrial stress test, $1 \mu \mathrm{M}$ oligomycin, $2 \mu \mathrm{M} \mathrm{FCCP}$, and $0.5 \mu \mathrm{M}$ rotenone/antimycin A were added at the indicated time.

\section{Statistics}

Data were presented as means $\pm \mathrm{SD}$. Comparisons were performed by Student's $t$-test for two groups or ANOVA for multiple groups. Significance was established at $p<0.05$.

\section{DATA AVAILABILITY}

The data sets generated during the current study are available from the corresponding author on reasonable request.

\section{REFERENCES}

1. Campbell JE, Newgard CB. Mechanisms controlling pancreatic islet cell function in insulin secretion. Nat Rev Mol Cell Biol 2021;22:142-58.

2. Salinno C, Cota P, Bastidas-Ponce A, Tarquis-Medina M, Lickert H, Bakhti M. $\beta$-Cell maturation and identity in health and disease. Int J Mol Sci. 2019;20:5417.

3. Gao T, McKenna B, Li C, Reichert M, Nguyen J, Singh T, et al. Pdx1 maintains beta cell identity and function by repressing an alpha cell program. Cell Metab. 2014;19:259-71.
4. Nishimura W, Takahashi S, Yasuda K. MafA is critical for maintenance of the mature beta cell phenotype in mice. Diabetologia. 2015;58:566-74.

5. Papizan JB, Singer RA, Tschen SI, Dhawan S, Friel JM, Hipkens SB, et al. Nkx2.2 repressor complex regulates islet beta-cell specification and prevents beta-toalpha-cell reprogramming. Genes Dev. 2011;25:2291-305.

6. Taylor BL, Liu FF, Sander M. Nkx6.1 is essential for maintaining the functional state of pancreatic beta cells. Cell Rep. 2013;4:1262-75.

7. Gu C, Stein GH, Pan N, Goebbels S, Hornberg H, Nave KA, et al. Pancreatic beta cells require NeuroD to achieve and maintain functional maturity. Cell Metab. 2010;11:298-310.

8. Creyghton MP, Cheng AW, Welstead GG, Kooistra T, Carey BW, Steine EJ, et al. Histone H3K27ac separates active from poised enhancers and predicts developmental state. Proc Natl Acad Sci USA. 2010;107:21931-6.

9. Talchai C, Xuan S, Lin HV, Sussel L, Accili D. Pancreatic beta cell dedifferentiation as a mechanism of diabetic beta cell failure. Cell. 2012;150:1223-34.

10. Prentki M, Matschinsky FM, Madiraju SR. Metabolic signaling in fuel-induced insulin secretion. Cell Metab. 2013;18:162-85.

11. Koyama K, Chen G, Wang M, Lee Y, Shimabukuro M, Newgard C, et al.beta-cell function in normal rats made chronically hyperleptinemic by adenovirus-leptin gene therapy. Diabetes. 1997;46:1276-80.

12. Stein DT, Esser V, Stevenson BE, Lane $K E$, Whiteside $J H$, Daniels $M B$, et al. Essentiality of circulating fatty acids for glucose-stimulated insulin secretion in the fasted rat. J Clin Invest 1996;97:2728-35.

13. Offermanns S. Free fatty acid (FFA) and hydroxy carboxylic acid (HCA) receptors. Annu Rev Pharmacol Toxicol 2014;54:407-34.

14. Stein DT, Stevenson BE, Chester MW, Basit M, Daniels MB, Turley SD, et al. The insulinotropic potency of fatty acids is influenced profoundly by their chain length and degree of saturation. J Clin Invest 1997;100:398-403.

15. Liakh I, Sledzinski T, Kaska L, Mozolewska P, Mika A. Sample preparation methods for lipidomics approaches used in studies of obesity. Molecules. 2020;25:5307.

16. Rios-Covian D, Ruas-Madiedo P, Margolles A, Gueimonde M, de Los Reyes-Gavilan CG, Salazar N. Intestinal short chain fatty acids and their link with diet and human health. Front Microbiol. 2016;7:185.

17. Wolever T, Josse R, Leiter L, Chiasson J. Time of day and glucose tolerance status affect serum short-chain fatty acid concentrations in humans. Metabolism. 1997;46:805-11.

18. Canfora EE, Jocken JW, Blaak EE. Short-chain fatty acids in control of body weight and insulin sensitivity. Nat Rev Endocrinol 2015;11:577-91.

19. Patel D, Singh S. Effect of ethanol and its metabolites on glucose mediated insulin release from isolated islets of rats. Metabolism. 1979;28:85-89.

20. Priyadarshini M, Villa SR, Fuller M, Wicksteed B, Mackay CR, Alquier T, et al. An acetate-specific GPCR, FFAR2, regulates insulin secretion. Mol Endocrinol. 2015;29:1055-66.

21. Pingitore A, Chambers ES, Hill T, Maldonado IR, Liu B, Bewick G, et al. The dietderived short chain fatty acid propionate improves beta-cell function in humans and stimulates insulin secretion from human islets in vitro. Diabetes Obes Metab 2017;19:257-65.

22. Pingitore A, Gonzalez-Abuin N, Ruz-Maldonado I, Huang GC, Frost G, Persaud SJ. Short chain fatty acids stimulate insulin secretion and reduce apoptosis in mouse and human islets in vitro: role of free fatty acid receptor 2 . Diabetes Obes Metab 2019;21:330-9.

23. Ximenes $\mathrm{H}$, Hirata A, Rocha M, Curi R, Carpinelli A. Propionate inhibits glucoseinduced insulin secretion in isolated rat pancreatic islets. Cell Biochem Func. 2007;25:173-8.

24. Tang C, Ahmed K, Gille A, Lu S, Grone HJ, Tunaru S, et al. Loss of FFA2 and FFA3 increases insulin secretion and improves glucose tolerance in type 2 diabetes. Nat Med 2015;21:173-7.

25. Itoh Y, Kawamata Y, Harada M, Kobayashi M, Fujii R, Fukusumi S, et al. Free fatty acids regulate insulin secretion from pancreatic beta cells through GPR40. Nature. 2003:422:173-6.

26. Priyadarshini M, Wicksteed B, Schiltz GE, Gilchrist A, Layden BT. SCFA receptors in pancreatic beta cells: novel diabetes targets? Trends Endocrinol Metab 2016;27:653-64.

27. Boets E, Gomand SV, Deroover L, Preston T, Vermeulen K, De Preter V, et al. Systemic availability and metabolism of colonic-derived short-chain fatty acids in healthy subjects: a stable isotope study. J Physiol 2017;595:541-55.

28. Tan J, McKenzie C, Potamitis M, Thorburn AN, Mackay CR, Macia L. The role of short-chain fatty acids in health and disease. Adv Immunol. 2014;121:91-119.

29. Pullen $T$, Rutter $G$. When less is more: the forbidden fruits of gene repression in the adult $\beta$-cell. Diabetes Obes Metab 2013;15:503-12.

30. Pullen TJ, Khan AM, Barton G, Butcher SA, Sun G, Rutter GA. Identification of genes selectively disallowed in the pancreatic islet. Islets. 2010;2:89-95.

31. Thorrez L, Laudadio I, Van Deun K, Quintens R, Hendrickx N, Granvik M, et al Tissue-specific disallowance of housekeeping genes: the other face of cell differentiation. Genome Res. 2011;21:95-105. 
32. Lemaire K, Thorrez L, Schuit F. Disallowed and allowed gene expression: two faces of mature islet beta cells. Annu Rev Nutr 2016;36:45-71.

33. Szollosi A, Nenquin $M$, Henquin J. Overnight culture unmasks glucose-induced insulin secretion in mouse islets lacking ATP-sensitive $\mathrm{K}^{+}$channels by improving the triggering $\mathrm{Ca}^{2+}$ signal. J Biol Chem 2007;282:14768-76.

34. Mosley AL, Corbett JA, Ozcan S. Glucose regulation of insulin gene expression requires the recruitment of $\mathrm{p} 300$ by the beta-cell-specific transcription factor Pdx-1. Mol Endocrinol 2004;18:2279-90.

35. Kataoka K, Han S, Shioda S, Hirai M, Nishizawa M, Handa H. MafA is a glucoseregulated and pancreatic beta-cell-specific transcriptional activator for the insulin gene. J Biol Chem 2002;277:49903-10.

36. Qiu $Y$, Guo M, Huang $S$, Stein R. Insulin gene transcription is mediated by interactions between the p300 coactivator and PDX-1, BETA2, and E47. Mol Cell Biol. 2002;22:412-20.

37. Oetjen E, Diedrich T, Eggers A, Eckert B, Knepel W. Distinct properties of the CAMPresponsive element of the rat insulin I gene. J Biol Chem 1994;269:27036-44.

38. Sabari BR, Zhang D, Allis CD, Zhao Y. Metabolic regulation of gene expression through histone acylations. Nat Rev Mol Cell Biol 2017;18:90-101.

39. Zhao S, Zhang X, Li H. Beyond histone acetylation-writing and erasing histone acylations. Curr Opin Struct Biol 2018;53:169-77.

40. Gao T, Díaz-Hirashi Z, Verdeguer F. Metabolic signaling into chromatin modifications in the regulation of gene expression. Int J Mol Sci 2018;19:4108.

41. Liu JL, Segovia I, Yuan XL, Gao ZH. Controversial roles of gut microbiota-derived short-chain fatty acids (SCFAs) on pancreatic beta-cell growth and insulin secretion. Int J Mol Sci 2020;21:910.

42. Boden G, Chen X, lqbal N. Acute lowering of plasma fatty acids lowers basal insulin secretion in diabetic and nondiabetic subjects. Diabetes. 1998;47:1609-12.

43. Komatsu M, Yajima H, Yamada S, Kaneko T, Sato Y, Yamauchi K, et al. Augmentation of $\mathrm{Ca}^{2+}$-stimulated insulin release by glucose and long-chain fatty acids in rat pancreatic islets: free fatty acids mimic ATP-sensitive $\mathrm{K}^{+}$channel-independent insulinotropic action of glucose. Diabetes. 1999;48:1543-9.

44. Crespin S, Greenough W, Steinberg D. Stimulation of insulin secretion by longchain free fatty acids. A direct pancreatic effect. J Clin Invest 1973;52:1979-84.

45. Hosokawa H, Corkey B, Leahy J. Beta-cell hypersensitivity to glucose following 24h exposure of rat islets to fatty acids. Diabetologia. 1997;40:392-7.

46. Leem J, Shim HM, Cho H, Park JH. Octanoic acid potentiates glucose-stimulated insulin secretion and expression of glucokinase through the olfactory receptor in pancreatic $\beta$-cells. Biochem Biophys Res Commun 2018;503:278-84.

47. Gao Z, Yin J, Zhang J, Ward RE, Martin RJ, Lefevre M, et al. Butyrate improves insulin sensitivity and increases energy expenditure in mice. Diabetes. 2009;58:1509-17.

48. Cani PD, Everard A, Duparc T. Gut microbiota, enteroendocrine functions and metabolism. Curr Opin Pharmacol 2013;13:935-40.

49. Haumaitre C, Lenoir O, Scharfmann R. Histone deacetylase inhibitors modify pancreatic cell fate determination and amplify endocrine progenitors. Mol Cell Biol 2008;28:6373-83.

50. Christensen D, Dahllöf M, Lundh M, Rasmussen D, Nielsen M, Billestrup N, et al. Histone deacetylase (HDAC) inhibition as a novel treatment for diabetes mellitus. Mol Med 2011;17:378-90.

51. Pasquali L, Gaulton KJ, Rodríguez-Seguí SA, Mularoni L, Miguel-Escalada I, Akerman I, et al. Pancreatic islet enhancer clusters enriched in type 2 diabetes riskassociated variants. Nat Genet 2014;46:136-43.

52. Tennant BR, Robertson AG, Kramer M, Li L, Zhang X, Beach M, et al. Identification and analysis of murine pancreatic islet enhancers. Diabetologia. 2013;56:542-52.

53. Rutter GA, Pullen TJ, Hodson DJ, Martinez-Sanchez A. Pancreatic beta-cell identity, glucose sensing and the control of insulin secretion. Biochem J. 2015;466:203-18.

54. Cobo-Vuilleumier N, Tuomi T, Cobo-Vuilleumier N, Koskela H, Odili S, Stride A, et al. Clinical heterogeneity in monogenic diabetes caused by mutations in the glucokinase gene (GCK-MODY). Diabetes Care. 2010;33:290-2.

55. Andrali SS, Sampley ML, Vanderford NL, Ozcan S. Glucose regulation of insulin gene expression in pancreatic beta-cells. Biochem J. 2008;415:1-10.

56. Philippe J, Missotten M. Functional characterization of a cAMP-responsive element of the rat insulin I gene. J Biol Chem 1990;265:1465-9.

57. Chakrabarti SK, Francis J, Ziesmann SM, Garmey JC, Mirmira RG. Covalent histone modifications underlie the developmental regulation of insulin gene transcription in pancreatic beta cells. J Biol Chem 2003;278:23617-23.

58. Khan S, Jena GB. Protective role of sodium butyrate, a HDAC inhibitor on beta-cell proliferation, function and glucose homeostasis through modulation of p38/ERK
MAPK and apoptotic pathways: study in juvenile diabetic rat. Chem Biol Interact 2014;213:1-12.

59. Lee S, Clark SA, Gill RK, Christakos S. 1,25-Dihydroxyvitamin D3 and pancreatic beta-cell function: vitamin $D$ receptors, gene expression, and insulin secretion. Endocrinology. 1994;134:1602-1610.

60. Goudarzi A, Zhang D, Huang H, Barral S, Kwon O, Qi S, et al. Dynamic competing histone $\mathrm{H} 4 \mathrm{~K} 5 \mathrm{~K} 8$ acetylation and butyrylation are hallmarks of highly active gene promoters. Mol Cell. 2016;62:169-80.

61. Nie L, Shuai L, Zhu M, Liu P, Xie ZF, Jiang $S$, et al. The landscape of histone modifications in a high-fat diet-induced obese (DIO) mouse model. Mol Cell Proteom. 2017;16:1324-34.

\section{ACKNOWLEDGEMENTS}

We thank all the participants included in this study. This work was funded by the National Natural Science Foundation of China (81770767, 81870526, and 81970691), Shanghai Municipal Education Commission-Gaofeng Clinical Medicine Grant (20191801), Science and Technology Commission of Shanghai Municipality (19140904400), and Shanghai Science and Technology Committee (20Y11905100).

\section{AUTHOR CONTRIBUTIONS}

SW and MY designed and performed the experiments, analyzed the data, and wrote the manuscript; KZ, CS, FZ, QL, and ZX performed the experiments; LZ performed the bioinformatics analysis; YL and JL provided technical support; LZ, XW, and JL supervised this study and wrote the manuscript. All authors read and approved the final paper.

\section{COMPETING INTERESTS}

The authors declare no competing interests.

ETHICS

The study did not require ethical approval.

\section{ADDITIONAL INFORMATION}

Supplementary information The online version contains supplementary material available at https://doi.org/10.1038/s41419-022-04517-1.

Correspondence and requests for materials should be addressed to Jieli Lu, Xiao Wang or Libin Zhou.

Reprints and permission information is available at http://www.nature.com/ reprints

Publisher's note Springer Nature remains neutral with regard to jurisdictional claims in published maps and institutional affiliations.

Open Access This article is licensed under a Creative Commons Attribution 4.0 International License, which permits use, sharing, adaptation, distribution and reproduction in any medium or format, as long as you give appropriate credit to the original author(s) and the source, provide a link to the Creative Commons license, and indicate if changes were made. The images or other third party material in this article are included in the article's Creative Commons license, unless indicated otherwise in a credit line to the material. If material is not included in the article's Creative Commons license and your intended use is not permitted by statutory regulation or exceeds the permitted use, you will need to obtain permission directly from the copyright holder. To view a copy of this license, visit http://creativecommons. org/licenses/by/4.0/.

(c) The Author(s) 2022 